Brit. J. industr. Med., 1964, 21, 315.

\title{
PLASMA PORPHYRINS IN LEAD WORKERS
}

\author{
BY \\ H. A. WALDRON \\ From the Medical Department, Vauxhall Motors Ltd., Luton
}

(RECEIVED FOR PUBLICATION MAY 15, 1964)

\begin{abstract}
Plasma porphyrin levels were determined in a group of 50 workers exposed to lead. The mean value obtained $(0.7 \mu \mathrm{g} . / 100 \mathrm{ml}$.) was found to be higher than that obtained from a control group $(0.2 \mu \mathrm{g} . / 100 \mathrm{ml}$.). Although urinary porphyrin levels in the lead workers were also higher than in the control group, no correlation was found between plasma porphyrin levels and urinary porphyrin levels.

Chromatography of the plasma porphyrins from lead workers showed that some protoporphyrin was present in addition to the coproporphyrin found in plasma from the control group.
\end{abstract}

\section{Introduction}

The effects of lead on urinary and erythrocyte porphyrin concentrations have been extensively studied and are now well known, but comparatively little work has been done to determine its effect on plasma porphyrin levels, and the results are conflicting. Van den Bergh and Hyman (1929) found that serum porphyrin concentrations were not raised in lead poisoning, although de Langen (1949) was able to demonstrate large amounts of porphyrin, on a qualitative basis, in the serum of a horse with experimental lead poisoning. Vigliani and Waldenström (1937) investigated 11 patients with plumbism and determined plasma porphyrin levels in seven of them. Of these seven patients, three had plasma porphyrin levels of 2-6 $\mu \mathrm{g} . / 100 \mathrm{ml}$., and porphyrin was demonstrated qualitatively in the plasma of the other four.

Recently a chromatographic method has been described for estimating plasma porphyrin (Schlenker, Davis, and Kitchell, 1961). The porphyrin is adsorbed on to prepared Florisil 500F resin and subsequently eluted with a solution containing acetone, ether, and glacial acetic acid. This method is capable of a high degree of accuracy, and has been used to perform plasma porphyrin estimations in a group of workers exposed to lead in this factory. The results have been compared with the levels in urine from the same workers, to see whether plasma porphyrin levels could be used to estimate exposure.

\section{Methods}

Blood was collected by venepuncture and heparinized, care being taken to avoid haemolysis during collection. The plasma was separated within an hour of collection and used only if it was clear and free from traces of haemoglobin. Plasma porphyrin concentrations were determined in a group of 50 workers exposed to lead and in a similar group of persons with no industrial exposure to lead as a control. Urinary coproporphyrin concentrations and haemoglobin concentrations were also determined.

Porphyrin estimations were carried out according to the methods described by Schlenker et al. $(1961,1963)$ with slight modifications as follows:

Plasma Porphyrin.-One ml. of dry Florisil 500F resin was introduced into a chromatography tube having approximate dimensions of $8 \times 350 \mathrm{~mm}$. (Discarded serological pipettes are suitable for this purpose.) The resin was treated in succession with $2.0 \mathrm{ml} .2 .5 \mathrm{~N} \mathrm{HCl}$, $4 \mathrm{ml}$. de-ionized water, $4 \mathrm{ml}$. acetone, and $4 \mathrm{ml}$. deionized water.

Plasma, 3-5 ml., was diluted with two volumes of water and the $\mathrm{pH}$ was adjusted to $1.0 \pm 0.25$ with $\mathrm{HCl}$. Any precipitate which formed on adding the $\mathrm{HCl}$ was dispersed by stirring.

The diluted plasma was added to the resin column and, after it had flowed through, the column was washed with water until the eluate was protein-free. (A convenient method for determining this is to test the eluate with Albustix.*)

\footnotetext{
* Ames Bros.
} 
When the eluate was protein-free, porphyrin was eluted from the column into graduated tubes with $5 \mathrm{ml}$. of an eluting solution consisting of acetone, ether, and glacial acetic acid in the ratio of 5:5:1 (v/v/v). The column was scanned under ultraviolet light to ensure that all the porphyrin had been eluted and, if so, $1 \mathrm{ml}$. of an extracting solution consisting of $2 \cdot 5 \mathrm{~N} \mathrm{HCl}$ in $10 \%(\mathrm{w} / \mathrm{v})$ ammonium chloride was added to the eluate and the tube was shaken vigorously. The tube was allowed to stand for five to 10 minutes to allow complete phase separation after which time the upper layer was discarded. The lower aqueous phase was then adjusted to $5 \mathrm{ml}$. with water.

The optical density of the solution was determined in the spectrophotometer against $0.5 \mathrm{~N} \mathrm{HCl}$ at 380 and $430 \mathrm{~m} \mu$ and at $1 \mathrm{~m} \mu$ intervals between 400 and $407 \mathrm{~m} \mu$ in cells having an optical path of $1 \mathrm{~cm}$. Plasma porphyrin concentrations were determined from the following equation:

$$
\begin{aligned}
& 2 \mathrm{D} \max -(\mathrm{D} 380+\mathrm{D} 430) \\
& \frac{\text { final vol., ml. }}{\text { plasma vol., ml. }} \times 100.82 \times
\end{aligned}
$$

D $\max =$ maximum optical density obtained between 400 and $407 \mathrm{~m} \mu$.

Urinary Porphyrin.-Florisil resin, $1 \mathrm{ml}$., was prepared as described above and to it was added $10 \mathrm{ml}$. of urine at $p \mathrm{H} 1 \cdot 0 \pm 0 \cdot 25$. When the urine had flowed through the resin column it was washed with $4 \mathrm{ml}$. de-ionized water and the porphyrin was eluted with $5 \mathrm{ml}$. of the eluting solution. If all the porphyrin had not been eluted (as shown by fluorescence in the column under ultraviolet light) a further $5 \mathrm{ml}$. of eluting solution was used.

Extracting solution, $1 \mathrm{ml}$., (or $2 \mathrm{ml}$. if $10 \mathrm{ml}$. eluting solution was used) was added to the eluate, and the phases were separated after five to 10 minutes. The aqueous phase was made up to $5 \mathrm{ml}$. (or $10 \mathrm{ml}$. if $2 \mathrm{ml}$. of extracting solution was used), and the optical density of the solution was determined against $0.5 \mathrm{~N} \mathrm{HCl}$ at 380,430 , and $401 \mathrm{~m} \mu$ using cells of $1 \mathrm{~cm}$. optical path.

Coproporphyrin concentrations were determined from the formula:

$$
\begin{aligned}
& \text { 2D } 401-(\mathrm{D} 380+\mathrm{D} 430) \times 73 \times \\
& \frac{\text { final vol., } \mathrm{ml} .}{\text { urine vol., } \mathrm{ml} .}=\mu \mathrm{g} . \text { coproporphyrin } / 100 \mathrm{ml} \text {. }
\end{aligned}
$$

Chromatography of plasma and urinary porphyrins was carried out by the method of Eriksen (1953) using an ascending technique and a developing solution of $2: 6$ lutidine/water $(5: 3)$. Porphyrins were extracted onto acidified talc and eluted from the talc with dilute $\mathrm{NH}_{4} \mathrm{OH}$ and applied to the chromatography paper in this solvent (Nicholas and Rimington, 1949).

Haemoglobin was determined by standard methods taking $14.6 \mathrm{~g}$. as $100 \% \mathrm{Hb}$.

\section{Results}

The results of the porphyrin estimations are represented in the Table. The mean of the plasma

\begin{tabular}{|c|c|c|c|c|}
\hline & \multicolumn{2}{|c|}{$\begin{array}{l}\text { Plasma Porphyrin } \\
(\mu \mathrm{g} . / 100 \mathrm{ml} .)\end{array}$} & \multicolumn{2}{|c|}{$\begin{array}{l}\text { Urinary Coproporphyrin } \\
(\mu \mathrm{g} . / 100 \mathrm{ml} .)\end{array}$} \\
\hline & Mean & Range & Mean & Range \\
\hline Test & 0.7 & $0.0-2.9$ & $10 \cdot 6$ & $0 \cdot 7-69 \cdot 8$ \\
\hline Control & 0.2 & $0.0-0.9$ & $2 \cdot 7$ & $0.3-7.8$ \\
\hline
\end{tabular}
porphyrin levels found in the lead workers was
TABLE

PLASMA AND URINARY PORPHYRIN LEVELS

markedly higher than that obtained from the control group. Thirty-seven of the lead workers $(74 \%)$ had plasma porphyrin levels greater than $0.2 \mu \mathrm{g} . / 100 \mathrm{ml}$. (the mean of the normal values), and $11(22 \%)$ had values in excess of $0.9 \mu \mathrm{g} . / 100 \mathrm{ml}$., the upper limit of the normal values. Two values were above $2.0 \mu \mathrm{g} . / 100 \mathrm{ml}$., the lowest level found by Vigliani and Waldenström (1937) in their patients with lead poisoning. The normal values found are in good agreement with those quoted by Schlenker $e$ t al. (1961) of 0 to $0.7 \mu \mathrm{g}$. $100 \mathrm{ml}$., and of 0.2 to 0.5 $\mu \mathrm{g} . / 100 \mathrm{ml}$. given by Ward and Mason (1950).

Higher urinary coproporphyrin levels were found in the lead workers than in the control group, as one would expect, but no correlation was found to exist between plasma porphyrin concentrations and urinary coproporphyrin concentrations (Fig. 1).

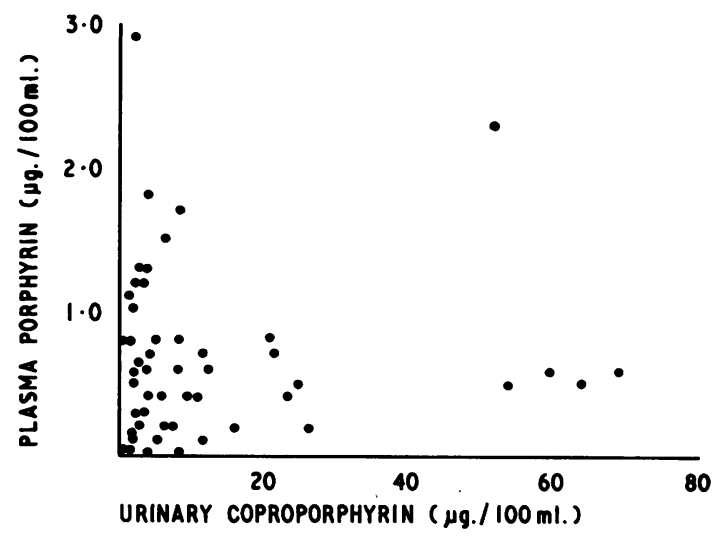

Fig. 1.-Urinary coproporphyrin values of the lead workers plotted against plasma porphyrin values.

Chromatographic analysis of the plasma porphyrins showed only coproporphyrin to be present in the control group but some protoporphyrin was also found in the plasma from the lead workers.

Analysis of the urinary porphyrins showed that in all but four of the lead workers only coproporphyrin was being excreted. In three of the other four, a porphyrin was found with an $\mathrm{Rf}$ of 0.65 , and in the fourth case a porphyrin with an $\mathrm{Rf}$ of 0.33 was found. These $\mathrm{Rf}$ values would correspond to porphyrins with three and six carboxyl groups respectively. 


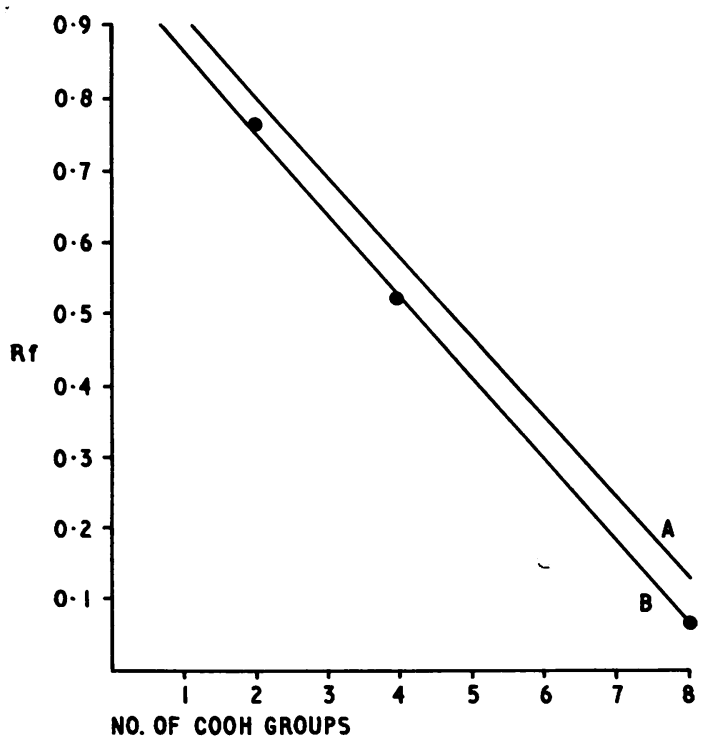

Fig. 2.-Relationship between $\mathbf{R f}$ and number of carboxyl groups. Curve constructed from (A) Eriksen's (1953) Rf values; (B) Rf values obtained by author.

In general the $R f$ values found were slightly lower than those of Eriksen (1953), but a good linear relationship between $\mathrm{COOH}$ groups and $\mathrm{Rf}$ values was observed. Figure 2 shows a curve constructed from $\mathbf{R f}$ values obtained by chromatographing samples of coproporphyrin, uroporphyrin, and protoporphyrin.* A curve constructed from Eriksen's values is shown for comparison.

No difference was found in the haemoglobin values of the two groups. The mean $\mathrm{Hb}$ value for the lead workers was $97 \%$ (range $86-106 \%$ ) and for the control group the mean was $98 \%$ (range $86-110 \%$ ).

*Coproporphyrin was obtained from Professor C. Rimington and uroporphyrin and protoporphyrin from Dr. D. C. Nicholson, to both of whom the author is most grateful.

\section{Discussion}

The results of the experiments described in this paper indicate that the levels of plasma porphyrin are greater in lead workers than in persons with no exposure to lead. None of the persons included in this study had any clinical signs of lead intoxication, but, even so, two workers had levels of plasma porphyrin within the range found by Vigliani and Waldenström (1937) in their cases of lead poisoning.

It was found, however, that there was no correlation between urinary and plasma porphyrin levels (Fig. 1), so that plasma porphyrin levels cannot be used to estimate exposure. The variation is such that they appear to be only incidentally related to lead poisoning. It is known that erythrocyte porphyrins, particularly protoporphyrin (Rubino, Pagliardi, Prato, and Giangrandi, 1958; Watson, 1950; Wranne, 1960), are increased in plumbism, and it may be that the high plasma porphyrin levels found in lead workers arise from the release of porphyrin during the normal break-down of the red cells in vivo. In this context it is interesting to note that protoporphyrin was identified chromatographically in the plasma of lead workers whereas only coproporphyrin was found in that of the controls. In view of these results the variations found by earlier workers is not surprising.

I am grateful to Dr. A. R. Thompson and the Management of Vauxhall Motors Ltd. for permission to publish this paper.

\section{REFERENCES}

Eriksen, L. (1953). Scand. J. clin. Lab. Invest., 5, 155.

de Langen, C. D. (1949). Acta med scand 133,73.

Nicholas, R. E. H., and Rimington, C. (1949). Scand. J. clin. Lab.

Invest., 1, 12.
$\mathrm{F}$ Brit. J. Haemat., 4, 103.

Schlenker, F. S., Davis, C. L., and Kitchell, C. L. (1961) Amer. J. clin. Path., 36, 31.

,

Vigliani, E. C., and Waldenström, J. (1937). Dtsch. Arch. klin. Med.. $180,182$.

van den Bergh, A. A. H., and Hyman, I. A. J. (1929). Ned. Maandschr. Geneesk., 15, 387 .

Ward, E., and Mason, H. L. (1950). J. clin. Invest., 29, 905.

Watson, C. J. (1950). A.M.A. Arch. int. Med.. 86, 297

Wranne, L. (1960). Acta Paediat. (Uppsala), 49, Suppl. 124. 